\title{
TITLE INDEX OF VOLUME 12
}

\begin{tabular}{lclr}
\hline EDITORIALS & $1,57,89$ & - Ecology and Development & 76 \\
LETTER TO THE EDITOR & 89 & & 106
\end{tabular}

\section{UNITED NATIONS ACTIVITIES}

UN / GA

- Environment discussed

Oil Pollution (Marpol)

Bonn Agreement

ECE

- More Rational Use of Water

- The Twelfth Session

UNESCO

- First International Congress on Biosphere Reserves

IMO (R.H. Ganten)

UNEP

- Ozone: Draft Convention Not Finalized

- Chemical and Pesticides in International Trade

- Hazardous Waste - Toward International Agreement (M.J. Foster)

- Documentation for the 12th Session (Introductory Report)

UNCTAD

- Tropical Timber Agreement

UN / ECE

- Little Progress Achieved at 39th Session
- The International Oil Pollution Compensation Fund

(T. Bruha)

Acid Rain Meeting

LDC: The Admissibility of Sub-Seabed Disposal of High-Level Radioactive Waste (H. Welsch)

Elizabeth Haub Prize

- Allocution de Monsieur Heribert Rausch

Ramsar: Second Conference of Contracting Parties

OECD

- Movements of Hazardous Waste

Pollution du Rhin. La Portee du Droit International dans l'Affaire de la Pollution du Rhin (A. Rest)

Export of Chemicals

\section{REGIONAL ACTIVITIES}

South Pacific Forum

EP

- Pollution of the North Sea

EC

- Uncontrolled Discharge of Clophen Banned

- High Cost of Acid Rain

- Safety at Sea

\section{NATIONAL AFFAIRS}

Belgium

- Illegal shipment of Ivory

46

Denmark

- Conservation Legislation and General Protection of Biotopes in an International Perspective (V. Koester)

Germany, Fed. Rep. of

- Environmentally Sound Development 51

- Waste to Gobi Desert?

France

Le Rhin et les MDPA: Annulation des arretes d'autorisation de deversement (P. Kromarek)

Sudan

- Policy Towards the Environment

Switzerland

- Environmental Protection Act

Uganda

- Serious Problems in all Four National Parks

UK

- Immersion of Nuclear Waste Suspended

USA

- Polluter Must Pay

- Sentenced

- Changes at Interior

- Policy Change

- Shipment Forfeited

- Additional \$37.2 Million to States through Fish and Wildlife Federal Aid

- Arctic Peregrine Falcon Reclassified to "Threatened" USSR

Environment on the Agenda

106

\section{SELECTED DOCUMENTS}

UN / GA

- Resolutions Submitted by the Second Committee

UNESCO

- First International Biosphere Reserve Congress (Recommendations)

OECD

- Decision and Recommendation of the Council on Transfrontier Movements of Hazardous Waste

- Information Exchange Related to Export of Banned or Severely Restricted Channels (Recommendation of the Council)

- Convention on Wetlands of International Importance Especially as Waterfowl Habitat; Conference of the Contracting Parties (Amendment of the Convention)

CEDE

- Principles Concerning International Co-operation in Environmental Emergencies Linked to Technological Development 


\section{UN/ECE}

- Senior Advisers - Twelfth Session

- Programme of Work 1984-1988

- Outline for National Reviews of Environmental Policies and Strategies in ECE Countries

- Tentative Schedule of Meetings

- Future Activities on International Measures for the Protection of Flora, Fauna and their Habitats (Task

Force Recommendations
1983 South Pacific Forum

Acid Rain: Canada-Europe Ministerial Conference

EC

- European Foundation for Safety at Sea (Motion for a Resolution)

UNEP

- Hazardous Wastes (Ad hoc Group of Experts on the Environmentally Sound Management of Hazardous Wastes)
84

86

\section{AUTHOR INDEX OF VOLUME 12}

Bruha, Thomas, 68

Forster, Malcolm J., 64

Ganten, R.H., 5

Koester, Veit, 106
Kromarek, P., 43

Rest, A., 6

Smets, H., 13

Welsch, Hubertus, 72 